\title{
The effects of physical activity on anxiety, depression, and quality of life in elderly people living in the community
}

\author{
Efeitos da atividade física sobre ansiedade, depressão e qualidade de vida em \\ idosos da comunidade
}

\author{
Lucineide da Silva Santos Castelo Branco de Oliveira, ${ }^{1}$ (D) Edila C. Souza, ${ }^{2}$ Rosilene Andrade Silva Rodrigues, ${ }^{1}$ \\ Carlos Alexandre Fett, ${ }^{3}$ Angelo Biagini Piva ${ }^{4}$
}

\begin{abstract}
Introduction: Health problems may negatively affect the psychological and physical aspects of life, influencing the quality of life of older adults. The objective of this study was to analyze the effects of physical activity on quality of life, anxiety, and depression in the elderly population.

Methods: We performed a cross-sectional study of 200 elderly people of both genders. Subjects were divided into two groups: one with 100 senior citizens engaged in physical activities in a social center for the elderly; and another composed of 100 subjects who lived in the community but were not engaged in physical activities. The instruments used to assess physical activities, quality of life, and anxiety and depression were, respectively: the modified Baecke questionnaire; the 36-Item Short Form Health Survey (SF-36); and the Hospital Anxiety and Depression Scale (HADS). The data were analyzed using the Student's $t$ test, Pearson's $r$, and analysis of variance (ANOVA), with odds ratio and a $5 \%$ significance level $(p<0.05)$.

Results: We observed that the active group showed higher scores of physical activity and quality of life. Conversely, the sedentary group revealed higher scores of anxiety and depression. Data assessment revealed a strong correlation between the domains quality of life, level of vitality, and mental health $(r=0.77)$. The prevalence ratio showed that physical activity is a protective factor against anxiety and depression in the elderly.

Conclusion: The findings suggest a correlation between low levels of physical activity and symptoms of anxiety and depression in the elderly living in the community.

Keywords: Aging, organic mental disorders, physical activity, scales.
\end{abstract}

\section{Resumo}

Introdução: Problemas de saúde podem afetar negativamente nos aspectos físicos e psicológicos, influenciando a qualidade de vida dos idosos. O objetivo deste estudo foi analisar os efeitos da atividade física sobre a qualidade de vida, ansiedade e depressão na população idosa.

Métodos: Foi realizado estudo transversal com 200 idosos de ambos os sexos, divididos em dois grupos: um grupo com 100 idosos envolvidos em atividades físicas do centro social para idosos; outro composto por 100 sujeitos que viviam na comunidade, mas não estavam envolvidos em atividades físicas. Os instrumentos utilizados para avaliação das atividades físicas, qualidade de vida, ansiedade e depressão foram, respectivamente: - questionário de Baecke modificado; o Questionário de Qualidade de Vida (SF-36); e a Escala Hospitalar de Ansiedade e Depressão (HADS). Os dados foram analisados por testes $t$ de Student, Pearson ( $r$ ) e análise de variância (ANOVA), com odds ratio e nível de significância de $5 \%(p<0,05)$.

Resultados: Observamos que o grupo ativo apresentou maiores escores de atividade física e qualidade de vida. Por outro lado, o grupo sedentário revelou maiores escores de ansiedade e depressão. A avaliação dos dados revelou uma forte correlação entre os domínios qualidade de vida, nível de vitalidade e saúde mental $(r=0,77)$. A razão de prevalência mostrou que a atividade física é fator de proteção contra ansiedade e depressão em idosos.

Conclusão: Os achados sugerem uma correlação entre baixos níveis de atividade física e sintomas de ansiedade e depressão em idosos que vivem na comunidade.

Palavras-chave: Envelhecimento, transtornos mentais orgânicos, atividade física, escalas.

\footnotetext{
${ }^{1}$ Secretaria Estadual de Saúde do Estado de Mato Grosso, Cuiabá, MT, Brazil. ${ }^{2}$ Universidade Federal de Mato Grosso (UFMT), Cuiabá, MT, Brazil. ${ }^{3}$ Núcleo de Aptidão Física, Informática, Metabolismo, Esporte e Saúde (NAFIMES), UFMT, Cuiabá, MT, Brazil. ${ }^{4}$ Universidade Federal de Uberlândia (UFU), Uberlândia, MG, Brazil. Submitted Feb 14 2018, accepted for publication Jun 272018.

Suggested citation: de Oliveira LSSCB, Souza EC, Rodrigues RAS, Fett CA, Piva AB. The effects of physical activity on anxiety, depression, and quality of life in elderly people living in the community. Trends Psychiatry Psychother. 2019;41(1):36-42. Epub Feb 04 2019. http://dx.doi.org/10.1590/2237-6089-2017-0129
} 


\section{Introduction}

With the aging process, quality of life (QOL) among the elderly population may gradually decrease. ${ }^{1} \mathrm{QOL}$ can be conceptualized as the harmonious set of satisfactions that individuals get in their daily lives, which considers the physical, psychological, and social aspects of life.1,2 Good QOL for the elderly can be defined as feeling better, properly carrying out their basic activities of daily living (ADLs), and living independently. ${ }^{3}$ Therefore, QOL becomes a target for programs aimed at assisting the elderly. ${ }^{4}$

Currently, we observe an increased incidence of psychological disorders in the elderly. The World Health Organization (WHO) estimates that approximately one of every 10 older adults might suffer from depression. ${ }^{5}$ Depression is the second most common cause of physical and psychosocial disability in the general population, ${ }^{6,7}$ falling behind only cardiovascular diseases. ${ }^{8}$ It is a mental disorder often associated with increased psychological distress in the elderly. Some depressive symptoms may appear in the elderly due to the use of multiple medications, or after other psychiatric disorders, such as obsessive-compulsive disorder or panic disorder. . $^{5,9,10}$

Anxiety is characterized by widespread, excessive, and unrealistic worries about daily life events or activities. This psychiatric disorder is also common in health professionals. Anxiety symptoms may occur on most days for at least six months. The most common symptoms include tachycardia, sleep problems, sweating, dizziness, gastrointestinal disorders, and nausea. ${ }^{11,12}$

Thus, depression produces a delay in therapeutic response and worsens prognosis in patients with anxiety disorders, ${ }^{10}$ most likely leading to suicide attempts in geriatric patients. ${ }^{13}$ All of these factors impair $\mathrm{QOL}$, favoring social isolation and the appearance of severe cases of clinical diseases. ${ }^{14,15}$

Physical activity is defined as any bodily movement produced by skeletal muscles that requires expenditure of energy ${ }^{16}$ greater than resting levels, such as walking, dancing, gardening, climbing stairs, among other activities. ${ }^{17}$ Physical exercise, in turn, is defined as planned, structured, repetitive bodily movements (prescribed by professionals or not) performed to improve or maintain one or more components of physical fitness.17,18 Therefore, physical activities performed by the elderly either at home or in social centers - contribute to a more active lifestyle.

Conversely, it is known that a sedentary lifestyle may cause physiological changes, as it reduces maximum aerobic capacity, muscle strength, motor responses, and overall functional capacity. A sedentary lifestyle also leads to a decrease in the capacity to conduct ADLs, thus interfering with the quality of life among older individuals. ${ }^{19}$ Therefore, the aging process associated with a sedentary lifestyle favors mental, social, and physical dependence. ${ }^{20}$

Rehabilitative interventions must be programmed in order to meet the needs of each individual. ${ }^{21}$ For this reason, regular physical activity practice should be a common habit in order to break the vicious circle of sedentary lifestyle, diseases, and incapacity. ${ }^{19,22}$ Moreover, physical exercise may contribute to greater social participation, resulting in biopsychophysical benefits, and hence improving the QOL of the elderly. ${ }^{23}$

In this context, assessing QOL, anxiety, depression, and physical activity levels (PAL) seems especially important in the elderly, since these aspects can speed up or slow down the symptoms associated with the prevalence of chronic degenerative diseases. ${ }^{24}$ However, few data have been published in the literature about PAL among elderly people in the city of Cuiabá, either to support national and international comparisons or to suggest indicators for possible public health interventions.

Therefore, the aim of this general study was to evaluate PAL and its relationship with QOL, anxiety, and depression in the elderly. Our specific aim was to compare QOL, anxiety, and depression levels of sedentary and physically active older adults to assess the correlation between PAL and the presence of anxiety and depression in the community-dwelling older adults.

\section{Methods}

\section{Sample}

We performed a cross-sectional study of 200 elderly people, 100 recruited at the Padre Firmo Duarte Social Center for the Elderly and 100 subjects who lived in the same community but were not engaged in physical activities, in Cuiabá, capital city of the state of Mato Grosso, Brazil. This study was approved by the ethics committee of Hospital Universitário Júlio Müller (protocol 632/09).

In order to classify the participants of the study as physically active or sedentary, we applied the modified Baecke questionnaire for older adults, in which individuals with scores equal to or lower than 9.4 are classified as sedentary. ${ }^{25,26}$ Anxiety and depression were assessed with the Hospital Anxiety and Depression Scale (HADS). The questionnaire was divided into two subscales, HADS-anxiety and HADS-depression. Scores for each subscale were categorized as follows: 0-8 points, without anxiety or depression; $\geq 9$ points, 
with anxiety or depression.27,28 QOL was evaluated using the 36-Item Short Form Health Survey (SF-36) questionnaire in the elderly population. ${ }^{29}$

\section{Data collection}

The interviews were carried out in the premises of the Padre Firmo Social Center for the Elderly and the data were collected by the research team. All participants signed a written informed consent form prior to having their data collected.

\section{Statistical analysis}

We used the Shapiro-Wilk test to check the distribution of data samples. After that, we used descriptive statistics to calculate mean and standard deviation (SD) for the analyzed variables. We used unpaired Student's $t$-test for independent samples to compare the results of the two groups (active and sedentary). We used Pearson's correlation ( $r$ ) to establish the possible relationship between the variables. ANOVA was used to detect possible differences between HADS-A and HADS-D. Pearson's chi-square test and logistic regression analysis were used with stepwise criteria for selection of variables, with measures of effect expressed as prevalence ratio. We adopted a $5 \%$ significance level $(p<0.05)$.

\section{Results}

The sample of this study consisted of 200 noninstitutionalized elderly. Of this total, 156 (78\%) were female and $44(22 \%)$ were male. There were 100 sedentary elderly ( 21 men and 79 women) and 100 active elderly (23 men and 77 women). The mean \pm SD ages of the sedentary and active subjects were $72.49 \pm 5.6$ and $69.93 \pm 4.5$ years, respectively. The variables with the greatest variability were physical aspects (50.25 \pm 43.98$)$ and emotional aspects $(77.00 \pm 39.88)$. Mean scores obtained for the anxiety (HADS-A) and depression (HADS-D) scales showed a

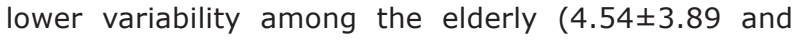
$4.47 \pm 3.98$, respectively) (Table 1 ).

Table 1 shows a comparison between PAL (sedentary vs. active elderly) and the variables of the SF-36 questionnaire (functional capacity, limitations due to physical aspects, pain, general health status, vitality, social aspects, emotional aspects, and mental health). The analysis showed statistical differences between the means of the SF-36 questionnaire and mean QOL scores. Active elderly scored higher in all aspects. We found positive and statistically significant correlations between all variables. We also observed a moderate correlation between the functional capacity domain of the SF-36 and PAL.

Table 2 shows comparisons across all variables: older people without any symptoms, older people with anxiety, older people with depression, and older people with anxiety/depression. We observed statistically significant differences between mean PAL and SF-36 questionnaire scores for the anxious, depressed, and anxious/ depressed groups. All mean PAL scores and SF-36 scores were lower in the anxious/depressed elderly group.

The elderly with higher anxiety and depression scores correlated moderately and negatively with SF-36 mental health scores (statistically significant

Table 1 - Comparison of variables between sedentary and active elderly living in the community

\begin{tabular}{|c|c|c|c|}
\hline Variables & Sedentary & Active & $\mathbf{p}$ \\
\hline Age (years) & $72.56 \pm 5.68^{\mathrm{a}}$ & $69.75 \pm 4.36^{\mathrm{b}}$ & 0.0001 \\
\hline Physical activity level & $5.81 \pm 2.31^{a}$ & $15.81 \pm 5.48^{b}$ & $<0.0001$ \\
\hline Anxiety scale (HADS-A) & $5.23 \pm 3.94^{a}$ & $3.78 \pm 3.71^{b}$ & 0.0001 \\
\hline Depression scale (HADS-D) & $5.81 \pm 4.16^{a}$ & $3.01 \pm 3.22^{b}$ & $<0.0001$ \\
\hline Functional capacity & $58.51 \pm 26.41^{\mathrm{a}}$ & $76.35 \pm 24.95^{b}$ & $<0.0001$ \\
\hline Physical aspects & $37.26 \pm 41.37^{a}$ & $64.32 \pm 42.57^{b}$ & $<0.0001$ \\
\hline Ache or pain & $64.17 \pm 27.28^{a}$ & $74.61 \pm 27.87^{\mathrm{b}}$ & 0.0081 \\
\hline General state of health & $71.62 \pm 17.99^{a}$ & $79.22 \pm 16.54^{b}$ & 0.0022 \\
\hline Vitality & $62.93 \pm 23.18^{a}$ & $76.72 \pm 21.46^{b}$ & $<0.0001$ \\
\hline Social aspects & $72.84 \pm 31.71^{a}$ & $89.45 \pm 19.56^{b}$ & $<0.0001$ \\
\hline Emotional aspects & $71.79 \pm 42.77^{a}$ & $82.64 \pm 35.86^{b}$ & 0.0500 \\
\hline Mental health & $69.46 \pm 24.78^{a}$ & $78.79 \pm 20.22^{b}$ & 0.0041 \\
\hline
\end{tabular}

Data presented as mean \pm standard deviation and scores, unless otherwise specified.

HADS-A = Hospital Anxiety and Depression Scale - Anxiety Scale; HADS-D = Hospital Anxiety and Depression Scale - Depression Scale. Means followed by different lowercase letters within rows differ statistically from each other (Student's test at $5 \%$ ). 
differences). We also observed that elderly people with higher vitality scores presented a strong correlation with mental health scores (Table 3).

The prevalence ratio obtained showed that physical activity is a protective factor against anxiety and depression in the elderly (Table 4).

The logistic regression model was adjusted with stepwise selection, and the protection ratio occurred in the categories with no symptoms for the variables general state of health and mental health score (Table 5).

\section{Discussion}

This study found that physically active elderly individuals had significantly higher overall QOL scores than their sedentary counterparts, who had the lowest results and a statistically significant relationship with anxiety and depression. However, from a physiological point of view, the aging process does not necessarily occur simultaneously to the advance of chronological age. Aging can be influenced by multiple combined factors,

Table 2 - Comparison between mean results obtained for HADS questionnaire variables

\begin{tabular}{|c|c|c|c|c|c|}
\hline Variables & $\begin{array}{l}\text { No symptoms } \\
(n=143)\end{array}$ & $\begin{array}{c}\text { Anxious } \\
(n=19)\end{array}$ & $\begin{array}{c}\text { Depressive } \\
\text { (23) }\end{array}$ & $\begin{array}{c}\text { Anxious/depressive } \\
(n=15)\end{array}$ & $\mathbf{p}$ \\
\hline Physical activity level & $11.66 \pm 6.82^{a}$ & $9.27 \pm 4.85^{\mathrm{ab}}$ & $7.91 \pm 5.04^{b}$ & $6.36 \pm 3.49^{b}$ & 0.0015 \\
\hline Age (years) & $71.22 \pm 5.29^{a}$ & $70.21 \pm 5.12^{\mathrm{a}}$ & $70.96 \pm 4.99^{a}$ & $72.73 \pm 5.81^{\mathrm{a}}$ & 0.5772 \\
\hline Functional capacity & $72.48 \pm 25.22^{\mathrm{a}}$ & $62.11 \pm 27.95^{\mathrm{ab}}$ & $53.91 \pm 23.64^{b}$ & $42.00 \pm 29.39^{b}$ & $<0.0001$ \\
\hline Physical aspects & $58.57 \pm 42.70^{a}$ & $46.05 \pm 46.59^{\mathrm{ab}}$ & $26.09 \pm 36.52^{\mathrm{b}}$ & $13.33 \pm 31.15^{\mathrm{b}}$ & $<0.0001$ \\
\hline Ache or pain & $73.99 \pm 26.33^{a}$ & $58.47 \pm 20.32^{\mathrm{ab}}$ & $63.39 \pm 29.18^{\mathrm{ab}}$ & $45.87 \pm 34.70^{b}$ & 0.0003 \\
\hline Vitality & $77.69 \pm 18.01^{a}$ & $58.42 \pm 21.99^{b}$ & $45.65 \pm 21.81^{b}$ & $42.67 \pm 23.21^{b}$ & $<0.0001$ \\
\hline Social aspects & $87.50 \pm 23.22^{\mathrm{a}}$ & $71.71 \pm 25.63^{\mathrm{ab}}$ & $65.76 \pm 34.59^{b}$ & $51.67 \pm 30.57^{b}$ & $<0.0001$ \\
\hline Emotional aspects & $86.25 \pm 32.70^{\mathrm{a}}$ & $63.16 \pm 44.30^{b}$ & $63.77 \pm 45.96^{b}$ & $26.67 \pm 42.16^{c}$ & $<0.0001$ \\
\hline Mental health & $83.27 \pm 15.56^{a}$ & $60.84 \pm 19.85^{b}$ & $48.87 \pm 23.79 b c$ & $40.00 \pm 19.06^{c}$ & $<0.0001$ \\
\hline
\end{tabular}

Data presented as mean \pm standard deviation and scores, unless otherwise specified.

HADS = Hospital Anxiety and Depression Scale.

Means followed by different lowercase letters within rows differ statistically from each other (Tukey test at $5 \%$ ).

Table 3 - Correlation matrix of SF-36 questionnaire domains with the variables analyzed

\begin{tabular}{|c|c|c|c|c|c|c|c|c|c|c|c|}
\hline & $\begin{array}{c}\text { Physical } \\
\text { activity } \\
\text { level }\end{array}$ & $\begin{array}{c}\text { Anxiety } \\
\text { scale } \\
\text { HADS-A }\end{array}$ & $\begin{array}{c}\text { Depression } \\
\text { scale } \\
\text { HADS-D }\end{array}$ & $\begin{array}{c}\text { Functional } \\
\text { capacity }\end{array}$ & $\begin{array}{l}\text { Physical } \\
\text { aspects }\end{array}$ & $\begin{array}{c}\text { Ache or } \\
\text { pain }\end{array}$ & $\begin{array}{c}\text { General } \\
\text { state of } \\
\text { health }\end{array}$ & Vitality & $\begin{array}{c}\begin{array}{c}\text { Social } \\
\text { aspects }\end{array} \\
\end{array}$ & $\begin{array}{c}\text { Emotional } \\
\text { aspects }\end{array}$ & $\begin{array}{l}\text { Mental } \\
\text { health }\end{array}$ \\
\hline Age (years) & $\begin{array}{l}-0.25 \\
(0.00)\end{array}$ & $\begin{array}{l}-0.03 \\
(0.67)\end{array}$ & $\begin{array}{c}0.04 \\
(0.54)\end{array}$ & $\begin{array}{l}-0.21 \\
(0.00)\end{array}$ & $\begin{array}{l}-0.18 \\
(0.01)\end{array}$ & $\begin{array}{l}-0.11 \\
(0.11)\end{array}$ & $\begin{array}{l}-0.08 \\
(0.24)\end{array}$ & $\begin{array}{l}-0.06 \\
(0.41)\end{array}$ & $\begin{array}{l}-0.16 \\
(0.03)\end{array}$ & $\begin{array}{l}-0.06 \\
(0.41)\end{array}$ & $\begin{array}{c}0.10 \\
(0.17)\end{array}$ \\
\hline Physical activity level & & $\begin{array}{l}-0.19 \\
(0.01)\end{array}$ & $\begin{array}{c}-0.35 \\
(<0.001)\end{array}$ & $\begin{array}{c}0.38 \\
(<0.001)\end{array}$ & $\begin{array}{c}0.29 \\
(<0.001)\end{array}$ & $\begin{array}{c}0.25 \\
(0.00)\end{array}$ & $\begin{array}{c}0.32 \\
(<0.001)\end{array}$ & $\begin{array}{c}0.34 \\
(<0.001)\end{array}$ & $\begin{array}{c}0.30 \\
(<0.001)\end{array}$ & $\begin{array}{c}0.17 \\
(0.02)\end{array}$ & $\begin{array}{c}0.24 \\
(0.00)\end{array}$ \\
\hline Anxiety scale (HADS-A) & & & $\begin{array}{c}0.52 \\
(<0.001)\end{array}$ & $\begin{array}{c}-0.28 \\
(<0.001)\end{array}$ & $\begin{array}{c}-0.32 \\
(<0.001)\end{array}$ & $\begin{array}{c}-0.32 \\
(<0.001)\end{array}$ & $\begin{array}{c}-0.38 \\
(<0.001)\end{array}$ & $\begin{array}{c}-0.51 \\
(<0.001)\end{array}$ & $\begin{array}{c}-0.36 \\
(<0.001)\end{array}$ & $\begin{array}{c}-0.43 \\
(<0.001)\end{array}$ & $\begin{array}{c}-0.63 \\
(<0.001)\end{array}$ \\
\hline $\begin{array}{l}\text { Depression scale } \\
\text { (HADS-D) }\end{array}$ & & & & $\begin{array}{c}-0.41 \\
(<0.001)\end{array}$ & $\begin{array}{c}-0.41 \\
(<0.001)\end{array}$ & $\begin{array}{l}-0.25 \\
(0.00)\end{array}$ & $\begin{array}{c}-0.44 \\
(<0.001)\end{array}$ & $\begin{array}{c}-0.61 \\
(<0.001)\end{array}$ & $\begin{array}{c}-0.39 \\
(<0.001)\end{array}$ & $\begin{array}{c}-0.38 \\
(<0.001)\end{array}$ & $\begin{array}{c}-0.64 \\
(<0.001)\end{array}$ \\
\hline Functional capacity & & & & & $\begin{array}{c}0.51 \\
(<0.001)\end{array}$ & $\begin{array}{c}0.45 \\
(<0.001)\end{array}$ & $\begin{array}{c}0.39 \\
(<0.001)\end{array}$ & $\begin{array}{c}0.62 \\
(<0.001)\end{array}$ & $\begin{array}{c}0.41 \\
(<0.001)\end{array}$ & $\begin{array}{c}0.29 \\
(<0.001)\end{array}$ & $\begin{array}{c}0.40 \\
(<0.001)\end{array}$ \\
\hline Physical aspects & & & & & & $\begin{array}{c}0.42 \\
(<0.001)\end{array}$ & $\begin{array}{c}0.23 \\
(0.00)\end{array}$ & $\begin{array}{c}0.48 \\
(<0.001)\end{array}$ & $\begin{array}{c}0.42 \\
(<0.001)\end{array}$ & $\begin{array}{c}0.41 \\
(<0.001)\end{array}$ & $\begin{array}{c}0.38 \\
(<0.001)\end{array}$ \\
\hline Ache or pain & & & & & & & $\begin{array}{c}0.18 \\
(0.01)\end{array}$ & $\begin{array}{c}0.43 \\
(<0.001)\end{array}$ & $\begin{array}{c}0.41 \\
(<0.001)\end{array}$ & $\begin{array}{c}0.26 \\
(0.00)\end{array}$ & $\begin{array}{c}0.33 \\
(<0.001)\end{array}$ \\
\hline General state of health & & & & & & & & $\begin{array}{c}0.55 \\
(<0.001)\end{array}$ & $\begin{array}{c}0.21 \\
(<0.001)\end{array}$ & $\begin{array}{c}0.19 \\
(0.01)\end{array}$ & $\begin{array}{c}0.48 \\
(<0.001)\end{array}$ \\
\hline Vitality & & & & & & & & & $\begin{array}{c}0.52 \\
(<0.001)\end{array}$ & $\begin{array}{c}0.38 \\
(<0.001)\end{array}$ & $\begin{array}{c}0.77 \\
(<0.001)\end{array}$ \\
\hline Social aspects & & & & & & & & & & $\begin{array}{c}0.43 \\
(<0.001)\end{array}$ & $\begin{array}{c}0.48 \\
(<0.001)\end{array}$ \\
\hline Emotional aspects & & & & & & & & & & & $\begin{array}{c}0.45 \\
(<0.001)\end{array}$ \\
\hline
\end{tabular}

HADS-A = Hospital Anxiety and Depression Scale - Anxiety Scale; HADS-D = Hospital Anxiety and Depression Scale - Depression Scale; SF-36 = 36-Item Short Form Health Survey.

Correlation of the Pearson ( $r$ ), 95\% confidence interval.

$\mathrm{p}<0.05$. 
which include biological aging, disease occurrence, and certain lifestyle patterns, such as low PAL. ${ }^{30}$

In our study, the highest scores obtained by the physically active older adults indicated a better QOL. ${ }^{1}$ Therefore, the high scores observed for the various domains in this group (physical and social aspects, vitality, and functional capacity) had a positive influence on functional independence among elderly adults. Also, the highest scores obtained for the functional capacity domain were statistically associated with better general health state, in agreement with another study. ${ }^{3}$

It has been suggested that functional limitations influence the behavior of older people. ${ }^{14}$ In the SF36, a high score for the physical appearance domain suggested that physically active elderly people had little professional or ADL limitation. ${ }^{10}$ Thus, physical activity, when performed collectively, promoted both physical and psychological improvements. ${ }^{9}$ The SF36 also revealed that individuals with higher levels of involvement in social relationships were more active. Thus, we can say that the higher the level of personal relationship involvement, the greater the social support the elderly receive. ${ }^{14}$

In the social context, physical activity promotes better integration in society. In addition, it improves satisfaction with life and reduces solitude. ${ }^{14}$ Our results are in agreement with other studies that show a positive relationship between physical activity and improved QOL. ${ }^{31}$

Our study also revealed that regular practice of physical activity promotes low levels of anxiety and depression in the elderly population. The researched social center offers several activities for the elderly that contribute to an active lifestyle, such as leisure and cultural activities, dancing classes, intellectually stimulating activities, craft activities, and group interaction. ${ }^{20}$ Other studies ${ }^{20,31}$ emphasize that the practice of physical activity boosts self-esteem in seniors, promoting psychosocial development and emotional rebalancing.

Other results revealed a moderate positive correlation between functional capacity and PAL, showing that the elderly people with better functional ability levels were engaged in regular exercise practice. Thus, it is suggested that regular physical activity can contribute to improved QOL. ${ }^{1,26}$ In the present study, when comparing the results of anxiety and depression symptom measurements, a statistically significant difference was found. ${ }^{14}$ Elderly people who exhibited symptoms of anxiety and depression had poorer QOL and a sedentary lifestyle. ${ }^{1}$ Therefore, physical self-perception in the elderly increases their sense of competence, 32 making them believe in their ability to perform ADLs. These findings suggest that

Table 4 - Results of the prevalence ratio according to level of physical activity of the elderly

\begin{tabular}{lcccccccccc}
\hline \multirow{2}{*}{ Category } & \multicolumn{4}{c}{ Active } & \multicolumn{4}{c}{ Sedentary } \\
\cline { 2 - 10 } & $\mathbf{n}$ & $\mathbf{\%}$ & $\mathbf{P R}_{\mathbf{c}}$ & $\mathbf{9 5 \% \mathbf { ~ I }}$ & $\mathbf{p}$ & $\mathbf{n}$ & $\mathbf{\%}$ & $\mathbf{P R}_{\mathbf{c}}$ & $\mathbf{9 5 \%} \mathbf{C I}$ & $\mathbf{p}$ \\
\hline No symptoms & 78 & 39.00 & 1.00 & - & - & 65 & 32.50 & 1.00 & - \\
With symptoms whole sample & 18 & 9.00 & 0.38 & {$[0.20-0.74]$} & 0.004 & 39 & 19.50 & 2.60 & {$[1.36-4.97]$} & 0.004 \\
Anxiety & 9 & 4.50 & 0.75 & {$[0.29-1.96]$} & 0.23 & 10 & 5.00 & 1.33 & {$[0.51-3.48]$} & 0.23 \\
Depression & 6 & 3.00 & 0.29 & {$[0.11-0.79]$} & 0.27 & 17 & 8.50 & 3.40 & {$[1.27-9.12]$} & 0.27 \\
Anxiety/depression & 3 & 1.50 & 0.21 & {$[0.06-0.77]$} & 0.12 & 12 & 6.00 & 4.80 & {$[1.30-17.74]$} & 0.12 \\
\hline
\end{tabular}

$95 \% \mathrm{CI}=95 \%$ confidence interval $; \mathrm{PR}_{\mathrm{c}}=$ crude prevalence ratio. $\mathrm{p}<0.05$ (chi-square).

Table 5 - Results of the logistic regression model using stepwise selection

\begin{tabular}{lccc}
\hline Variable/category & PR $_{\mathbf{a}}$ & $\mathbf{9 5 \%} \mathbf{C I}$ & $\boldsymbol{p}$ \\
\hline $\begin{array}{l}\text { General state of health (score) } \\
\text { With symptoms }\end{array}$ & 1.00 & - & - \\
$\quad$ No symptoms & 0.96 & {$[0.94-0.99]$} & 0.003 \\
& & & - \\
Mental health (score) & 1.00 & - & - \\
$\quad$ With symptoms & 0.93 & {$[0.91-0.95]$} & $<0.0001$ \\
$\quad$ No symptoms & &
\end{tabular}

40 - Trends Psychiatry Psychother. 2019;41(1) 
sedentary seniors can become active by practicing 150 minutes of physical exercise during the week, ${ }^{20}$ which may improve their independency and mental wellbeing. Thus, it is important that health professionals implement rehabilitation programs that adopt an interdisciplinary approach. ${ }^{21}$

In our study, the percentages of anxiety and depressive symptoms in both the sedentary and active groups were lower when compared with another study. ${ }^{33}$ This may be due to the simple fact that our subjects were all from the same community. Another study found that, for some elderly, friends, family and social networks provide a sense of well-being. ${ }^{34}$

A study involving both genders that targeted rural elderly in Thailand showed that low-income and female sex showed significant associations with PAL, but at low or moderate intensity rates, probably due to walking and the performance of home tasks. ${ }^{35}$ Adjustment via logistic regression analysis yielded two important variables in relation to PAL: general health status and mental health. This result should be different in institutionalized elderly, since they tend to suffer more from loneliness or depression. Even planned exercises performed three times a week add benefits to vitality, as observed in our study. Therefore, exercising at least twice a week produces positive results. ${ }^{36}$

Finally, we suggest that family members should encourage older people to take part in physical activities and stimulate their participation in activities offered by social centers for the elderly. These simple measures could contribute to a better aging process. We plan to extend our research into this topic with further tests and examinations.

It was concluded that PAL may contribute to $\mathrm{QOL}$ and reduce the symptoms of anxiety and depression in the elderly. In this way, it can maintain physical and functional abilities, vitality and psychological state. Our study revealed that active seniors have better QOL and fewer symptoms of anxiety and depression than their sedentary peers do. Therefore, it is important that day centers for the elderly offer physical activities in public and private spaces. Among all strategies known to ensure the promotion of elderly health, the regular practice of physical activity in urban and regional health centers should be prioritized.

\section{Acknowledgment}

The authors would like to thank the elderly volunteers at Padre Firmo Duarte Social Center for the Elderly for participating in this study.

\section{Disclosure}

No conflicts of interest declared concerning the publication of this article.

\section{References}

1. Sampaio PY1, Ito E. Activities with higher influence on quality of life in older adults in Japan. Occup Ther Int. 2013;20:1-10.

2. Felce D, Perry J. Quality of life: its definition and measurement. Res Dev Disabil. 1995;16:51-74.

3. Bhamani MA, Khan MM, Karim MS, Mir MU. Depression and its association with functional status and physical activity in the elderly in Karachi, Pakistan. Asian J Psychiatr. 2015;14:46-51.

4. Tsang HW, Tsang WW, Jones AY, Fung KM, Chan AH, Chan EP, et al. Psycho-physical and neurophysiological effects of qigong on depressed elders with chronic illness. Aging Ment Health. 2013; 17:336-48.

5. World Health Organization (WHO). Depression: evidence-based recommendations for management of depression in nonspecialized health settings [Internet]. 2015 [cited 2018 Nov 5]. www.who.int/mental_health/mhgap/evidence/depression/en/

6. Chang YC, Yao G, Hu SC, Wang JD. Depression affects the scores of all facets of the WHOQOL-BREF and may mediate the effects of physical disability among community-dwelling older adults. PLoS One. 2015;10:e0128356.

7. Mihalca AM, Pilecka W. The factorial structure and validity of the hospital anxiety and depression scale (HADS) in Polish adolescents. Psychiatr Pol. 2015;49:1071-88.

8. World Health Organization (WHO). Cardiovascular disease [Internet]. 2015 [cited 2018 Nov 5]. www.who.int/cardiovascular_ diseases/en/

9. Li J, Theng YL, Foo S. Depression and psychosocial risk factors among community-dwelling older adults in Singapore. J Cross Cult Gerontol. 2015;30:409-22.

10. Uchmanowicz I, Gobbens RJ. The relationship between frailty, anxiety and depression, and health-related quality of life in elderly patients with heart failure. Clin Interv Aging. 2015;10:1595600.

11. Fernández AA, Granados JJM. Trastornos de ansiedad en el paciente anciano. Med - Programa Form Medica Contin Acreditado. 2015;11:5022-30.

12. Siegel AM, Mathews SB. Diagnosis and treatment of anxiety in the aging woman. Curr Psychiatry Rep. 2015;17:93.

13. Wakefield JC, First MB. Validity of the bereavement exclusion to major depression: does the empirical evidence support the proposal to eliminate the exclusion in DSM $\square$ 5? World Psychiatry. 2012;11:3-10.

14. Yi ES, Hwang HJ. A study on the social behavior and social isolation of the elderly Korea. J Exerc Rehabil. 2015;11:125-32.

15. Boss L, Branson S, Cron S, Kang DH. Spiritual pain in meals on wheels' clients. Healthcare (Basel). 2015;3:917-32.

16. World Health Organization (WHO). Physical activity [Internet]. 2018 [cited 2018 Nov 5]. www.who.int/topics/physical_activity/ en

17. Caspersen CJ, Powell KE, Christenson GM. Physical activity, exercise, and physical fitness: definitions and distinctions for health-related research. Public Health Rep. 1985;100:126-31.

18. Maciel MG. Atividade física e funcionalidade do idoso. Motriz. 2010;16:1024-32.

19. Penha JCL, Piçarro I da C, Barros Neto TL de. Evolução da aptidão física e capacidade funcional de mulheres ativas acima de 50 anos de idade de acordo com a idade cronológica, na cidade de Santos. Cien Saude Colet. 2012;17:245-53.

20. Souza AM, Fillenbaum GG, Blay SL. Prevalence and correlates of physical inactivity among older adults in Rio Grande do Sul, Brazil. PLoS One. 2015;10: e0117060.

21. Ferreira MS, Sonoda LT, Barbosa SA, Franco FG de M, Carvalho JAM de. Reabilitação física na síndrome de fragilidade do idoso. Acta Fisiatr. 2014;21:26-8.

22. Ciolac EG. Exercise training as a preventive tool for age-related disorders: a brief review. Clinics (Sao Paulo). 2013;68:710-7. 
23. Han K, Lee Y, Gu J, Oh H, Han J, Kim K. Psychosocial factors for influencing healthy aging in adults in Korea. Health Qual Life Outcomes. 2015;13:31.

24. Wang R, Yan Z, Liang Y, Tan EC, Cai C, Jiang H, et al. Prevalence and patterns of chronic disease pairs and multimorbidity among older Chinese adults living in a rural area. PLoS One. 2015;10:e0138521.

25. Voorrips LE, Ravelli AC, Dongelmans PC, Deurenberg $P$, Van Staveren WA. A physical activity questionnaire for the elderly. Med Sci Sports Exerc. 1991;23:974-9.

26. Eckert KG, Lange MA. Comparison of physical activity questionnaires for the elderly with the international classification of functioning, disability and health (ICF) - an analysis of content. BMC Public Health. 2015;15:249.

27. Zigmond AS, Snaith RP. The hospital anxiety and depression scale. Acta Psychiatr Scand. 1983;67:361-70.

28. Botega NJ, Bio MR, Zomignani MA, Garcia C Jr, Pereira WA. [Mood disorders among inpatients in ambulatory and validation of the anxiety and depression scale HAD]. Rev Saude Publica. 1995;29:359-63.

29. Ciconelli RM. Tradução para língua portuguesa e validação do questionário genérico de avaliação da qualidade de vida SF-36 (BRASIL, SF-36) [dissertation]. São Paulo: Universidade de São Paulo; 1997.

30. Vieira AAU, Aprile MR, Paulino CA. Exercício físico, envelhecimento e quedas em idosos: revisão narrativa. Rev Equilibrio Corporal Saude. $2014 ; 6: 23-31$
31. Lang PO, Vogel T. Bénéfices pour la santé de la pratique d'une activité physique chez le sujet âgé. Cah Ann Gérontol. 2013;5:257-67.

32. Unsar S, Dindar I, Kurt S. Activities of daily living, quality of life, social support and depression levels of elderly individuals in Turkish society. J Pak Med Assoc. 2015;65:642-6.

33. Kim H. Anxiety, depression and cognitive function of communitydwelling elderly in South Korea. Indian J Sci Technol. 2015;8:1-5.

34. Wang $X$. Subjective well-being associated with size of social network and social support of elderly. J Health Psychol. 2016;21:1037-42.

35. Ethisan P, Somrongthong R, Ahmed J, Kumar R, Chapman RS. Factors related to physical activity among the elderly population in rural Thailand. J Prim Care Community Health. 2017;8:71-6.

36. Rugbeer N, Ramklass S, Mckune A, van Heerden J. The effect of group exercise frequency on health related quality of life in institutionalized elderly. Pan Afr Med J. 2017;26:35.

\section{Correspondence:}

Lucineide da Silva Santos Castelo Branco de Oliveira

Rua Desembargador Trigo de Loureiro, 549, Edifício Eco Vita Ideali, apto. 1805, Torre 1, Bairro Consil

78048322 - Cuiabá, MT - Brazil

Tel.: +55 (65) 996602906

E-mail: lucineidebenvenuti@gmail.com 